Ankara Üniversitesi Türk Inkılâp Tarihi Enstitüsü Atatürk Yolu Dergisi S 40, Kasım 2007, s. 545-567

\title{
Demokrat Parti Dönemi Ekonomi Politikaları (1950-1957)
}

Yaşar BAYTAL*

\section{ÖZET}

Liberal ekonomiye geçiş, günümüze kadar gelen tartışmalı konulardan biridir. Zira Türkiye'de liberal ekonomideki dinamikler ekonomik kurallarla yaptlanmaktan ziyade siyasi kararlar sonucunda oluşmustur. Bu yüzden siyasi istikrarsizlık doğrudan ekonomiyi etkilemiş, halkın hiç alışık olmadı̆̆ ithalat furyası ve enflasyonist baskılarla sonuçlanmıştır. Bu çalışmanın amact, Demokrat Parti iktidarının ilk yıllarında gerçekleştirmeye çalıştığı ekonomik liberalleşme ve bunun doğurduğu sonuçlardır. Bu dönemde Türk ekonomisinde gözle görülür bir büyiume gerçekleştiği gibi dışa bağımlılık ta gittikçe artmıştır. Çıkarılan bir takım kanunlar, alınan dış borçlar, yabancı yatırımı teşvik gibi yasal ve siyasi düzenlemeler bunun göstergeleridir.

Anahtar Kelimeler: Demokrat Parti, Ekonomi, Liberal Ekonomi, Yabancı Sermaye.

\section{ABSTRACT}

Transition to liberal economy is one of the debatable subjects existing so far. Because dynamics in economy have come about due to political decisions ruther than economic rules. Therefore, political unsitability. Has influenced economy directly and ended with import rush the public aren't familiar with and inflationary pressures. The purpose of this study is the economic liberalism that Democratic Party tried to perform in the first years of its government and its results. Since a remarkable development occured in Turkish economy during that time, economic dependance to foreign countries increased. Some of the laws which were brought out, debts borrowed from foreign countries, legal and political policies such as

• Ankara Üniversitesi Türk İnkılâp Tarihi Enstitüsü Doktora Öğrencisi. 
encouragement of foreign investmnet are indications of economic dependance to foreign countries.

Keywords: Democrat Party, Economy, Liberal Economy, Foreign Capital.

\section{GíRiş}

Cumhuriyetin ilânının ardından her alanda geri kalmış olan ülkeyi düzlüğe çıkarmak için kararlı bir ekonomik politikaya ihtiyaç vardı. İlk dönemlerde, geleneksel Osmanlı ekonomik sistemi Cumhuriyet rejimiyle birlikte bir değişime uğradıysa da bununla ilgili ekonomik yönlendirmeler ve kararlar yeterli olmadı. ${ }^{1}$ Bunun en büyük nedeni, tarımsal teknolojideki geriliğe rağmen tarımın hâlâ zenginlik kaynağı olarak görülmesidir. Diğer neden ise, Osmanlı yönetim anlayışının bir gereği olarak ticaretin küçümsenmesi yüzünden Batıdaki gibi girişimci sınıfının doğmasını engellemiş olmasıdır. ${ }^{2}$ Osmanlı ekonomisinin usta-çırak ilişkisi şeklindeki yapılanması, ekonominin devlet tekelinden bağımsız olmasını engellemiş, rekabet gücüne dayanan liberal ekonomi kurallarını geçersiz kılmıştır. Devlet, piyasada rekabet sistemini canlı tutarken rekabetin rekabeti öldürmemesine de çaba göstermiş, bunun için etkili bir piyasa denetimi sağlamış, tekelci eğilimlerle mücadele etmiş ve fiyat istikrarının sağlanmasını sosyal refah için şart koşmuştur. Kısacası, "makul bir kârla yetinip aşır rekabeti reddetme konusundaki genel ĕ̆ilim” hem devlet ve hem de zanaat mensupları ile tüccarların yüzyıllardır değişmeyen geleneği haline gelmiştir. ${ }^{3}$

Cumhuriyet dönemi Türk ekonomisini güç durumda bırakan diğer bir olumsuzluk ise, Osmanlı İmparatorluğu'nu Avrupa'nın bir pazarı haline getiren kapitülasyonlardır. Kapitülasyonlar, İmparatorluk içindeki el sanatlarına dayalı üretimi yok ettiği gibi devletin Batılı devletlere daha bağımlı duruma gelmesini sağlamıştır. ${ }^{4}$

1 İsmet Ergün, "Dünden Bugüne Türkiye Ekonomisi ve İki binli Yıllara Bakış", Tarihi Gelişmeler İçinde Türkiye'nin Sorunları Sempozyumu (Dün-Bugün-Yarın), Ankara, 1995, s. 255 Bu sempozyum, H.Ü.A.İ.I.T.E. Tarafından 8-9 Mart 1990'da Ankara'da düzenlenmiștir.

${ }^{2}$ Ergün, a.g.m., s. 255-256; Şerif Mardin, Türk Modernleşmesi, (Makaleler 4), İstanbul 1991, s.227.

Mehmet Genç, "Osmanlı Esnafı ve Devlet", Osmanlı Imparatorluğunda Devlet ve Ekonomi, İstanbul, 2000 , s. 307.

${ }^{4}$ Osmanlı Devleti, kapitülasyonlanı verirken bir takım kurallara dikkat etmekteydi. Başlangıçta verilen ekonomik ayrıcalıkların fıkıh hükümleriyle çelişmemesine, devletin siyasî, ekonomik ve malî beklentilerine cevap vermesine özen gösterilirdi. Devlet, kapitülasyonları verirken siyasî beklentileri yanında, kendi sınırları içerisinde üretilmeyen veya kıt olan kumas, kalay ve çelik gibi maddeleri sağlamayı ve hazinenin başlıca gelir kaynağı olan gümrük gelirlerini artırmayı esas almaktaydı. Ancak sanayi devriminden sonra değişen ekonomik koşullar Osmanlı Devleti'nin bu konudaki denetim gücünü zayıflatmış, Batılıların pazarı haline getirmiştir. Ayrıntılı bilgi için bkz. Halil İnalcık, "İmtiyâzât", The Anclopedia of Islam, c. III, London 1971, s. 1179-1185; Necdet Kurdakul, Osmanll 


\section{Demokrat Parti Dönemi Öncesi Türk Ekonomisi}

Türkiye Cumhuriyeti’nin, devraldığı sözü edilen bütün bu olumsuzluklara karşın, Atatürk Lozan Antlaşması ile kazanılan siyasal bağımsızlığın elden gitmemesi için ekonomik bağımsızlığın da kaçınılmaz olduğuna inanıyordu. Bu görüșünü, 17 Şubat 1923'te toplanan İzmir İktisat Kongresi'ni açı̧ konuşmasında şu cümleyle açıklıyordu: “Ulusal egemenlik iktisadi egemenlik ile pekiştirilmelidir." ${ }^{5} \mathrm{Bu}$ sözlerle ekonomik bağımsızlığın yeni Türkiye devleti için ne kadar önemli olduğunu vurguluyordu. Atatürk önderliğindeki bu kongre ile Türkiye, liberal ekonomik düzeni benimsiyor, özel teşebbüsü koruma ve geliştirmeyi amaçlıyordu. ${ }^{6}$

İktisat Kongresi'nden sonra hükümet, ilk ulusal ticaret bankamız olan İş Bankasının 1924'te faaliyete geçmesini sağlamıştır. Ardından 1925 yılında Sanayi ve Maadin Bankasının kurulmasıyla sanayiyi destekleyici kredi sağlanması amaçlanmıştır. Çiftçi kesiminin de isteğine uyularak devlet bütçesine yaklaşık \% 30 gelir sağlayan Aşar Vergisi yürürlükten kaldırılmıştır. Yine 1927 yılındaki "Teşvik-i Sanayi Kanunu" ile sanayi yatırımları özendirilmeye çalışılmıştır. ${ }^{7}$

1929 ekonomik buhranı bütün dünyayı olduğu gibi Türkiye'yi de derinden etkilemiştir. 1923 'ten beri amaçlanan ekonomide liberalizm anlayışı, yerini devletin kaçınılmaz müdahalesine bırakmıştır. Dünyanın ve Türkiye'nin karşı karşıya bulunduğu ekonomik durumu çok iyi değerlendiren Atatürk ve hükümet ülkenin içinde bulunduğu ekonomik koşullara uygun olan önlemleri 1930 yılından itibaren yürürlüğe koymuştur. Başka bir deyişle ekonomide devletin ağırlığı git gide artmış, devletçiliğin gereği olan ekonomik yasalar ve kurallar geçerli olmuştur. ${ }^{8}$

Devletinde Kapitülasyonlar ve Ticaret Antlasmaları, İstanbul 1981, s. 23-32; Donald Blaisdel, Osmanlı İmparatorluğu'nda Avrupa Mali Denetimi, İstanbul, 1979, s. 32-55. Zafer Toprak, "Tanzimat'tan Cumhuriyet'e Osmanlı Ekonomisinde Gelişmeler (Tarım-TicaretSanayi), 1885-1985 Türkiye Ekonomisinin 100 Yllt ve İzmir Ticaret Odast Sempozyumu, (21-23 Kasum 1985), İzmir, s. 5.

5 Afetinan, Devletçilik Ilkesi ve T.C. Birinci Sanayi Planı 1933, Ankara, 1972, s. 42.

${ }^{6}$ Kongreye, tüccar, sanayici, işçi ve çiftçi temsilcileri de katılmasına rağmen, kongre kararlarının çoğu tüccarların ve büyük çiftçilerin lehine olduğu ortaya çıkmaktır. Kongrede çiftçiler, büyük toprak sahipleri tarafından temsil edilmiş, işçi ve köylülerin istekleri, diğer kesimlerin çıkarlarıyla ters düştüğünden sonuç alınamamıştır. Asker-sivil bürokrat ve eşraftan oluşan CHP'nin köylülerin istediği toprak reformu gibi radikal önerileri kabul ederek eşrafla karş1 karşıya gelmek istemediği açıktı. Bkz. Doğan Avcıŏlu, Türkiye'nin Düzeni, Dün Bugün Yarın, c. I, İstanbul, 1999,. s. 360.

7 Haluk Cillov, Türkiye Ekonomisi, İștanbul, 1970, s. 135-138; Ayrıca Bu konularla ilgili daha genis bilgi için bkz. Gündüz Ökçün, Türkiye İktisat Kongresi, Ankara 1968; TOBB-Türkiye'de Gayri Safi Milli Hasıla, 1923-1986, Ankara, 1987, s. 178; Ergün, a.g.m., s. 256-257.

${ }_{8}^{8}$ Sanayideki atılımlar gıda ve ulaşım gibi temel gereksinimlere yöneliktir. Bunlar yapılırken bütçe harcamaları kısıtlanmış yeni vergiler getirilmiş iç tüketim azaltılmıştır. Cillov, a.g.e., s. 137-138; Ergün, a.g.m., s. 256-257. 
1931'den itibaren Merkez Bankası'nın açılmasıyla ulusal ekonominin korunması kolaylaşmış, Osmanlı Bankası ve azınlıkların ulusal çıkarlara ters düşen karar ve uygulamalarına son verilmiştir. 1933'te ise Sümerbank'ın kurulmasıyla devletçiliğin taşıyıcı ve sürükleyici özelliği ile ulusal ekonomiye bir model oluşturulmaya çalışılmıştır."

1934'te Birinci Beş Yıllık Sanayi Planı Sovyet uzmanlarının yardımı ve Sovyet hükümetinin mali destek sözü ile hazırlandı. Plan uygulamaya konulduktan sonra Devletçilik uygulamalarına devam edildi. Enerji ve maden işletmelerini devlet denetimine almak ve merkezden yönetmek için 1935 yılında Etibank kuruldu. Diğer yandan çoğu yabancıların elinde bulunan bakır ve demir işletmeleri Etibank tarafından satın alındı ve Türkiye'nin yeraltı kaynaklarını araştırmak için Maden Tetkik ve Arama Enstitü kuruldu. 1938'de kurulan Halk Bankası bir kamu bankası olarak örgütlendi. ${ }^{10}$

Devletçiliğin etkin olarak uygulandığı bu yıllarda dış ticaret ikili antlaşmalara göre yürütülmüş, ithalat sınırlanması ile dış borçlar dengesi sağlanarak Türk lirasının değeri korunmuştur." 1935 'te devletçilikle ilgili uygulamaların ana ilkeleri ülkede tek siyasal örgüt olan CHP'nin programına konulmuş, ardından 1936 'da Birinci Sanayi Planı uygulaması devam ederken Celal Bayar başkanlığında Sanayi Kongresi toplanarak İkinci Sanayi Planı hazırlığına girişilmiştir. Ancak 1938 'de dünyada savaş rüzgarlarının esmesiyle bu plandan vazgeçilerek Íktisadî Savunma Plant' yürürlüğe konulmuştur. Bu çerçevede nüfusun büyük bir bölümü silâhaltına alındığı için iç tüketim çoğalmış buna bağlı olarak savaş yıllarında yaygın hale gelen mal kıtlığı yüzünden oluşan karaborsa yoluyla haksız kazanç elde edenlerin sayısı oldukça artmıştır. 26 Ocak 1940'de olağanüstü koşullarda, ulusal ekonomi ve savunmayı ilgilendiren konularda hükümete geniş yetki veren Milli Korunma Kanunu yürürlüğe konulmuştur. Bütün bu önlemlere karşın karaborsa devam etmiş stokçuluk dizginlenemez duruma gelmiştir.

Savaş zenginlerinin elde ettikleri servet, ekmeğini bile karneyle alạn halk arasında büyük tepkiye dönüşmüştür. Bunun üzerine CHP Meclis Grubu, 12 Kasım 1942'de Varllk Vergisini kabul ederek hem devlet

${ }^{9}$ Erdinç Tokgöz, "Cumhuriyet Döneminde Ekonomik Gelişmeler", Türkiye Cumhuriyeti Tarihi II, Ankara, 2002, s. 324.

1934 'de kabul edilen bu plana göre yatırımların 41.553.000 lirası Sümerbank tarafından gerçekleştirilecek, 2.400 .000 lirahı kısmı İs Bankası'nca yapılacaktır. Sümerbank yatırımlarının 10.515.000 liralık kısmı Rusya'dan getirilecektir. Emre Kongar, Devletçilik ve Günümüzdeki Sonuçları, Atatürk Döneminin Ekonomik ve Toplumsal Tarihiyle Illgili Sorunlar Sempozyumu, Yüksek İktisat ve Ticaret Mektebi Mezunları Derneği Yayınları, İstanbul, 14-16 Ocak 1977, s. 157; Birinci ve İkinci Sanayi Planlarının ekonomik ilkeleri için bkz. Ali Nejat Ölçen, "1923-1938 Döneminde Birinci ve İkinci Sanayi Planları", Atatürk Dönemi Ekonomi Politikası ve Türkiye'nin Ekonomik Gelişmesi Semineri. Ankara Üniversitesi Siyasal Bilgiler Fakültesi Basın Ve Yayın Yüksek Okulu Basımevi, Ankara, 1982, s. 136-138.

Tokgöz, a.g.m., s. 325 
gelirlerini arttırarak enflasyonla mücadele etmek hem de karaborsayla mücadele etmeyi amaçlamaktayd.$^{12}$ Her ne kadar ülkedeki Gayrimüslimler, bu verginin kendileri için çıkarıldı̆̆ını iddia etseler de söz konusu verginin belli servet birikimi olanlardan alındığı açıktır. ${ }^{13}$ Sonuçta İstanbul ve diğer büyük kentlerden alınan bu vergi, iç ve dış baskılar sonucu yürürlükten kaldırılmıştır.

İkinci Dünya Savaşı'nın ardından 1945 Türkiye'sinde siyasi güç ile ekonomik güç arasındaki çatışma yeni bir boyut kazandı. Zira hükümet muhalif söylemlere rağmen Çiftçiyi Topraklandırma Kanunu ${ }^{14}$ çıkarma ve ardında uygulamaya konmasıyla büyük toprak sahiplerinin başta Adnan Menderes, Emin Sazak, Cavit Oral ve Fevzi Karaosmanoğlu gibi kişilerin büyük tepkisiyle karşılaştı. ${ }^{15}$ Başlangıçta CHP'nin Toprak Reformu ve dolayısıyla ekonomi politikasına karşı oluşan bu muhalefet hareketi, siyasi bir harekete dönüștü. ${ }^{16} 1945$ yılı Haziranında Celal Bayar, Adnan Menderes, Fuat Köprülü ve Refik Koraltan'ın, iktidar partisi olan CHP'nin Meclis Grubuna bir takrir vererek Türk siyasi tarihinde "Dörtlü Takrir" olarak anılan hareketi başlatmışlar, ${ }^{17}$ ardından bu muhalif kadro, daha sonra CHP'den ayrılarak 7 Ocak 1946'da Demokrat Parti'yi kurmuşlardır.

12 Bkz. Korkut Boratav, Türkiye de Devletçilik, Ankara, 1982.

13 Bkz. Korkut Boratav, Türkiye de Devletçilik, Ankara, 1982 . hazırladığı duyulur. Gayrimüslim cemaat temsilcilerinden oluşan bir grup Ankara'ya gelerek Başbakan Şükrü Saraçoğlu'na alaycı bir öneri getirirler. Azınlık temsilcileri; “...Efendim, siz ne kadar vergi toplamayı düšünüyorsunuz? Üç yüz milyon mu toplamak istiyorsunuz yoksa iki yüz milyon mu toplamak istiyorsunuz? Siz bunu bize bırakın kendi aramızda toplayalım ve hükümetimize verelim..." derler. Ancak başbakan buna "Biz modern devletiz" diyerek gerekli cevabı vermistir. Bkz. Ayhan Aktar. "Varlık Vergisi ve İstanbul" Toplum ve Bilim. Sayı. 71 (1996), s. 193-194; Varlık Vergisini başka bir açıdan inceleyen makale için bkz. Edward C. Clark. "Türk Varlık Vergisine Yeniden Bakıș." Yapıt, Sayı. 8 (1984-1985). s. $29-43$. 8893-97.

"Çiftçiyi Topraklandırma Kanunu." T. C Resmi Gazete, 15 Haziran 1945, s.

Yasaya karşı çıkılmasının nedeni özel ormanların ve büyük toprak sahibi ailelerin bir kısmının arazilerinin kamulaştırılmak istenmesinden dolayıdır. Bkz. Asım M. Karaömerlioğlu. "Bir Tepeden Reform Denemesi: Ciftçiyi Topraklandırma Kanunu'nun Hikâyesi", Birikim, Sayı 107 (1998), s. 34-35; Çağlar Keyder-Şevket Pamuk. "1945 Çiftçiyi Topraklandırma Kanunu Üzerine Tezler." Yaptt, Sayı. 8 (1984-1985), s. 52-63.

${ }_{16}$ CHP'ye karș muhalif bir grubun olusturulması, CHP'nin 1939'daki 5. Kurultayında 30 kişilik müstakil grup kurma düşüncesiyle oluşmuş, ardından 1943 seçimlerinde aday sayısının seçilecek milletvekili sayısının iki katı olarak saptanması Celal Bayar ve arkadaşlarını cesaretlendirmis 7 Haziran 1945 'te "Dörtlü Takriri" vermelerinde etkili olmuştur. Sina Akşin, "Demokrat Parti’nin Kurulması", Tarih ve Toplum, c.IX, Sayı: 53, May1s 1988, s. 13.

${ }_{17}$ Toprak Kanunu tasarısı hakkında Meclis görüșmeleri bașladığında Meclis üyeleri iki gruba ayrılmıștır. Tasarının lehinde olanlar, konuya sosyal-entelektüel açıdan bakan "sivilbürokrat" kökenli üyelerdi. Muhalif milletvekilleri tasarının 17. maddesini eleştirirek tasarıdaki toprağın bölünmesi hususu, Anayasaya ters düsstüğünü iddia etmişlerdir. Bunlara göre özel mülkiyet, Anayasayla güvence altına alındığından 17. madde uygulanamaz nitelikteydi. Muzeffer Sencer, Türkiye'de Siyasal Partilerin Sosyal Temelleri, İstanbul, 1971, s. 197-198; Samet Ağaoğlu, Demokrat Partinin Doğus ve Yükseliş Sebepleri-Bir Soru. İstanbul, 1972, s. 155-160; "Dörtlui Takrir'in" tam metni için bkz. Rıfkı Salim Burçak, 
7 Ocak 1946'da kurulan DP, başlangıçta CHP'nin prensipleri olan "altı ok"a bağlılığını açıkça ortaya koyduğu gibi, devletin ekonomik politikası olan devletçiliği de serbest girişimciliğe daha çok olanak tanıyacak bir anlamda yorumlamaktaydı. Parti tüzügünde bu konudaki anlayış şu şekilde belirtilmekteydi:

"Devletçiliği, ekonomik alanda uzun zamandan beri devam eden boşluğu bir an öncce doldurmak, iş hacmini genişleterek yurttaşların geçim ve refah düzeyini yükseltmek için, devletin, gerek doğrudan doğruya ekonomik faaliyetlere girișmesi, gerekse teşvik ve yardım yollarl ile özel teşebbüs ve sermayenin genel yararlara en uyg un şekilde ve hızla gelişmesinde görev alması anlamında anlıyoruz... Özel teşebbüs menfaatleri genel menfaatin te'lifi ve korunmast zaruretinden ileri gelmektedir. Bizim devletçiliğimiz, ekonomik koşullarımızın çizdiğ $i$ yoldur" ${ }^{18}$ denilerek devletçilikte değişkenlik ilkesine yer verilmiştir. ${ }^{19}$ Devletçiliğe farklı bir bakış açısı getiren DP kurucuları, hükümeti erken seçime zorlayarak 1946 seçiminde 62 milletvekili ile Meclise girmeyi başardılar. Ardından 14 Mayıs 1950 seçimlerinde oyların \% 53'ünü alarak iktidar oldular.

\section{1950-1954 Demokrat Partili Yullar ve Türk Ekonomisi}

İktidar olarak DP'nin ekonomiye özel ilgi göstermesi çok önemliydi. Zira tek partili yönetimden bıkmış olan halk kitleleri DP'nin kurulmasının Türk siyasal yaşamına taze kan getireceğini düşünüyor ve bu partiden çok şeyler bekliyordu. Başta tek parti döneminde uygulanan yasalara karşı çıkarak puan toplamaya çalışan DP'liler, iktidar olduklarında popülist yaklaşımlarla bir takım yasaların düzenlenmesine giriştiler. Diğer yandan iktidarlarının hemen başından itibaren CHP'nin mal varlığı üzerinde durarak siyasi puan toplamaya çalıştılar.

DP'nin kuruluş felsefesindeki liberalizm anlayışı, ekonomide de etkisini gösterdi. Ekonomideki bu liberalizm anlayışı, bir düşünceden

Türkiye'de Demokrasiye Geçis 1945-1950, 1979, s. 241-244; Ünal Başdoğan, VII. TBMM Döneminde Türk Siyasî Hayatı (1943-1946), H.U.A.I.I.T.E., (Yayınlanmamış Yüksek Lisans Tezi), Ankara, 1995, s. 72.

${ }_{18}$ Demokrat Parti Tüzük ve Programı, İstanbul, 1946, s. 50-51, Madde 17.

19 Aslında CHP'nin 1948 Türkiye İktisat Kongresi'nde alınan kararlara bakıldığında devletçilik konusunda oldukça yumuşamış özel sektöre ağırlık veren bir anlayış içerisine girmiş olduğu görülmektedir. Bu yumuşamayı 1948 Türkiye İktisat Kongresi'nin "Devletçilik Hakkındaki Rapor ve Kararlar" bölümünde de görebiliriz. Bu rapor ve kararlarda: "Devletin ekonomi politikası, özel mülkiyete dayanan, bireyin ekonomik özgürlüklerini koruyan, ekonomi alanında özel girișimi esas tutan ve milli ekonomiye rehberlik eden ve sosyal adaleti önemle ele alan bir sistem olmalıdır" denilerek devletin işletmecilik görevinden kurtarılarak bireyin ekonomik özgürlügünü koruyan özel teşebbüsü esas tutan, milli ekonomiye rehberlik eden ve sosyal adaleti ele alan bir devletçilik modeli olşturulmaya çalışılmıștır. DP'nin devletçilik konusundaki görüşlerinin şekillenmesinde, bu kongrede alınan kararlarla büyük benzerlik göstermesi bakımından oldukça önemlidir. 1948 Türkiye İktisat Kongresi için bkz. http:/lekutup.dpt.gov.tr, s. 385-386. 
çok zorunluluktan kaynaklanan bir yaklaşımı ifade eder ${ }^{20}$ Zira 1952 'den sonra enflasyon ve döviz kurlarındaki önlenemez artış, söz konusu liberalizm politikasının diğer yüzünü gösterir. ${ }^{21}$ DP'nin liberalizm anlayışı, sadece özel sektöre yer verilmesi anlamında değil; devlet sektörünün de ekonomide yer almasını kaçınılmaz görüyordu. ${ }^{22}$ Bir yandan geleneksel tarım ekonomisinin devam ettirilmesi için devlet tarafından destek verileceği vurgulanırken diğer yandan da özellikle sanayi kuruluşlarında özel sektörün de yer alacağından söz ediliyordu. Konuyla ilgili olarak Menderes 26.5.1954 tarihinde hükümet programı dolayısıyla yaptı̆̆ konuşmada partisinin gerçekleştireceği ekonomik icraatları şöyle sıralıyordu:

1. "Nüfusumuzun \% 80'inin iştigal mevzuunu ve geçim vasıtasını, milli ekonomimizin temelini, sanayi ve ticaretimizin ana kaynă̆ını teşkil eden ziraatımız büyük bir dikkat ve ehemmiyetle ve ön planda ele alınacaktır.

2. Memleketin İktisadi cihazlandırılmast süratlendirilecek, bütün malî ve iktisadî imkânlarımız, azami nispette iktisadi kalkınmanın emrine tahsis olunacaktir.

3. Hususi teşebbüsün çalışması ve gelişmesi için lüzumlu hukuki ve fiili emniyet havasının yerleşmesini temine matuf bütüin tedbirler alınacaktır.

4.Yabancı teşebbüs, sermaye ve tekniğinden geniş ölçüde faydalanmanın şartlarl tahakkuk ettirilecek ve icaplarl yerine getirilecektir.

Devlet bütçelerinin cari hizmetler ve sarfiyatında azami tasarrufla hareket edilecek, memleketin iktisadi takatiyle mütenasip denk ve muvazeneli bütçeler getirilecek, buna mukabil iktisadi kalkınmaya ve bir kül halinde vatandaşların istihsal gayretleri ve faaliyetlerini desteklemeye matuf sermaye yatırımlarına mümkün olan en genis hissenin ayrılması temin edilecektir." ${ }^{23}$

Hükümet programında kırsal kesime de yer veren Menderes, program dolayısıyla konuşmasına şöyle devam ediyordu: "Köy yolları ve köprülerin inşaatı büyük nispette ikmal edilmiş, yol şebekemiz pek ziyade genişletilmiş, bugün inşalarına başladı̆̆ımız baraj ve elektrik santralleri ve modern tesislerinden çoğu işletmeye açılmıs, yeni barajlar ve santraller inșaatına da girişilmiş bulunacaktır. Köy elektrifikasyonu davasına da başlanmış ve hatta ilerletmiş olacă̆ız, radyo istasyonlarımızı, limanlar, hava meydanları,

20 Feroz Ahmad, The Turkish Experiment in Democracy 1950-1957, Published for The Royal Institute of International Affairs C. Hurst \& Company by London, 1977, s. 138-139.

Tevfik Çavdar, "Demokrat Parti”, Cumhuriyet Dönemi Türkiye Ansiklopedisi, c VIII, s. 2072-2073.

22 Mustafa Albayrak, Türk Siyasi Tarihinde Demokrat Parti, Ankara, 2004, s. 303.

${ }^{23}$ TBMM Zabit Ceridesi, D:10, c:I, Tarih: 24.5.1954, s. 26. 
silolar, depolama ve yükleme tesislerimizin inşaatını da ikmal etmiş bulunacağız." ${ }^{24}$

Başbakan Menderes, programın ikinci bölümünde ise, yeni dönemde yapmayı planladıkları konular üzerinde durarak, tarım ve sanayiye verilecek önemin yanı sıra, Türk parasının değerinin korunacağını, 1950'lerdeki ekonomik girişimciliğe devam edileceğini, ithalatın arttırılarak kaynakların daha iyi kullanılacağını, vergi konularında ıslahat yapılması yanında vergilerin sosyal adalet prensiplerine göre düzenleneceğini, toprak dağıtımın devam ettirileceğini, bildiren konușması yer alıyordu. Böylece programda belirtildiği gibi, tarıma öncelik verilecek, sanayileşme özel kesim öncülüğünde yürütülecek, dış ekonomik ilişkilerde devlet müdahalesi en az düzeye indirilecekti. DP, programında yer alan bu ilkelere, ülkedeki çeşitli iniş ve çıkışlara rağmen bağlı kaldığı söylenebilir. Daha sonraki Menderes hükümetlerinde de bu ekonomik program fazla değișmeden uygulanılmaya çalışılmıştır. ${ }^{25}$

\section{Yabanct Sermaye ve Petrol Kanunu}

Menderes hükümeti, ekonomide liberalizmin sağlanması için başta ABD olmak üzere, Batılı demokratik devletlerle daha sıkı bir işbirliğgi yapılacağını açıklayarak bir girişımci sınıfının doğmasını sağlamayı hedefliyordu. Bunda yabancı uzmanların önemli payı vardır. DP'nin iktidarı devraldığ 1950 yılından itibaren izlediği ekonomik politikaların çoğu Barker Raporu olarak bilinen Milletlerarası Imar ve Kalkınma Bankasının Menderes hükümetiyle yaptığı işbirliği sonucunda hazırlanmış olan rapora dayanıyordu. Raporda, Türkiye'nin ekonomik yapısı, geçmişte uygulanmış politikalar ve gelecekte uygulayabilecek ekonomik politikalar üzerinde duruluyordu. ${ }^{26}$

Menderes hükümeti, devletin sadece yerli girşimcilerle kalkınamayacağının farkındaydı..$^{27}$ Yabancı sermayenin Türkiye'ye gelmesini kolaylaştırmak için "Yabancı Sermaye Yatırımlarını Teşvik Kanunu” kabul edilerek Türk ekonomisi canlandırılmaya çalışıldı. Böylece, tek parti döneminde ekonomik açıdan özel sektörün aleyhinde olduğu ileri sürülen engeller kaldırıldı. Bu sektörün ekonomide yer alması için yapılan bir diğer düzenleme ise "Petrol Kanunu"dur.

${ }^{24}$ Faik Kırbaşlı, 1920-1972 Döneminde Kalkınmada Öncelikli Yörelere İişsin Hükümet Politikaları, Ankara, 1973, s. 113

${ }_{25}$ Albayrak, a.g.e., s. 304.

26 Albayrak, a.g.e., s. 305.

27 Menderes'in hükümet programında özel girisime ağırlık verilmesi gerektiği savunulurken uygulamada yeterince ses getirmemiştir. Aslında hükümet, özel kesimi finansal kurumlarla desteklemeye çalıșmıștır. 1951'de faaliyete geçen Türkiye Sınaî Kalkınma Bankası, özel kesime orta ve uzun vadeli sanayi yatırım kredisi vermek üzere, büyük ticaret bankalarınca örgütlenmişti. Bkz. Tokgöz, a.g.m., s. 333. 
Kanunun amacı, Türkiye'nin petrol kaynaklarının özel teşebbüs eli ve yatırımları ile süratle, kesintisiz ve verimli bir şekilde geliştirilip değerlendirilmesini sağlamaktı. ${ }^{28}$ Öncellikle Amerikan şirketlerinin bu konuya ilgi duydukları bilinmekteydi. Dönemin bakanı Sıtkı Yırçalı petrol yasa tasarısının o günkü dünya koşulları içinde Türkiye'nin çıkarlarını en iyi şekilde koruyup gözetildiğini ileri sürerek özel girişimin de içinde bulunacağı Türkiye Petrolleri Anonim Ortaklığı'nın kurulacağını ve bu ortaklığın MTA'nın çalışma alanları içerisinde bizzat yer alacağını belirtmiştir. ${ }^{29}$ Yasa tasarısının gerekçesinde, daha önceki Petrol Yasasının yerli ve yabancı özel kuruluşlar içerisinde daha teşvik edici hale getirilmesinin amaçlandığı ileri sürülmekteydi. ${ }^{30}$ Sonuçta petrol yasası 07 Mart 1954 tarihinde TBMM'de kabul edilmiştir. ${ }^{31} 29$ Mayıs 1957 'de ise 6326 sayılı kanunla yeniden düzenlenerek yatırımcılara ve yabancı şirketlere daha cazip hale getirilmiştir. ${ }^{32}$

Hükümetin ekonomi konusunda izlediği politika, başta ana muhalefet partisi CHP'yi harekete geçirdi. 1953 programıla ilk kez ekonomik ve sosyal sorunlara ağırlık vermeye başlayan CHP, 1954 Mart'ında artık iktidara karşı başta sosyal ve ekonomik sorunları ele alarak eleştirilerini yoğunlaştıracaktır. ${ }^{33}$ CHP'nin en büyük tepkisi petrol yasasından sonra olmuştur. CHP, bu yasayla kapitülasyonların yeniden verildiğini, ülkenin geri dönülmez çıkmazlara sürüklendiğini savunmaktaydı. Bu konularda iktidara en büyük tepki, CHP lideri İnönü tarafından gelmiştir. ${ }^{34}$

Diğer yandan, Mecliste ikinci muhalefet partisi olan Cumhuriyetçi Millet Partisi milletvekili Hikmet Bayur programı sert dille eleştirerek Türkiye için yeni hiç bir şey vaat etmediğini söylüyor ve konuşmasını şöyle devam ettiriyordu: "Hükümet programının önemli bir kısmı dört yıllık

28 Düstur, III. Tertip, c. XXXV, Kanun No: 6326, s. 1390; Zafer, 22 Ocak 1953; Hikmet Bilâ, Sosyal Demokrat Süreç İçinde CHP ve Sonrası. Baskı yeri yok, 1987, s. 210-211.

29 Ayın Tarihi, Mart 1954, s. 48-49.

TBMM Zabut Ceridesi, D: 10, c. VII, s. 270.

TBMM Zabut Ceridesi, D: 9, c. XXIX, K1sım: 1, s. 436-439.

:2 TBMM Kavanin Mecmuast, c. XXXVIII, s. 925-928.

33 Eleştirilerin ilk ciddi adımı 23.1.1923'te yürürlüğge giren kâr transferi ve sermayenin yatırım yapılan ülkeye gönderilmesine ilişkin sınırlamaların kaldırılması ile başladı. Bazı CHP'li vekiller, kanunla tarım, tarım sahaları ve ticaretin yabancı sermayedarların avantajlı hale getirildiğini ileri sürerek şiddetle eleştirdiler. Ulus, 19.1.1954.

${ }_{34}$ CHP ve onun lideri İsmet Paşa bu yasalara açık bir biçimde cephe alarak hükümeti ağır bir şekilde eleştirdi. İnönü, bu tür icraatların Lozan'da büyük mücadeleler sonunda kazanılmış olan ekonomik bağımsızlığımıza indirilen büyük darbeler olduğunu savundu. Petrol Kanunu ile ilgili olarak bkz. Düstur, III. Tertip, c. XXXV, Tarih: 7 Mart 1954, Kanun No: 6327; Avni Zarakoğlu, "Memleketimize Yabancı Sermaye İthali Bakımından Üç Devre", Forum, c. I, S. I, : (1 Nisan 1954), s. 11; Bilâ, a.g.e., s. 210-211; Cavdar, "Cumhuriyet Halk Partisi (1950-1980)", Cumhuriyet Dönemi Türkiye Ansiklopedisi, c. VIII, İstanbul, 1983, s. 2027. 
olayların kendi görüş açılarından tahlili ile sınırlı kalmakta ve bir Hükümet programindan çok bir mücadele nutku izlenimini vermektedir ${ }^{135}$ sözleriyle iktidara karşı eleştirilerini dile getiriyordu.

Fakat muhalefet partilerinin bütün bu sert eleştirilerine karşın, kendilerinin de ekonomi konusunda somut öneriler getirememesi, eleştirilerin sönük kalmasına neden olmuştur. Bu durum, DP'lilerin işine yaramış muhalefete rağmen ekonomi konusunda birçok yasaların kolay bir şekilde çıkarılmasını sağlamıştır. Zaten muhalefetin bu yasaları engelleyebilecek sayıca üstünlüğ̈ü de yoktu.

Muhalefete karşın ekonomideki bu düzenlemeler, Türkiye'yi dişa bağımlı duruma getirmekle birlikte, özellikle tarım ürünlerindeki ihracatın da artmasına neden olmuştu. 1950 'den sonra tarımda makineleşme Türkiye'nin bir tahıl ihracatçısı durumuna gelmesini sağlanmıştır. Dört yıl içinde (1950-1954 arasında) Türkiye, yılda \% 13'lük gibi hayli yüksek bir ekonomik büyüme yaşamasında tarımın etkisi oldukça fazladır. ${ }^{36}$

Ekonomide alınan bu olumlu gelişme sayesinde DP, iktidar olduğu ilk yıllara kıyasla bütçe açığını düzensiz de olsa kapatabilmiştir. İhracatın artması sadece bütçe açığını kapatmakla kalmamış GSMH'nın da artmasına neden olmuştur. Böylece 1954 'ten sonra kişi başına düşen ulusal gelir artışında da \% 3,5'luk bir oranla hiç küçümsenmeyecek bir başarıya ulaşılmıştır. ${ }^{37}$ Ancak bu başarı, kalıcı olmayacak ekonomideki bozulmayla birlikte bu iyimser hava da yok olacaktır.

Ekonomideki kötü gidişte, sadece DP hükümetinin uyguladığı yanlış politika değil, aynı zamanda kötü hava koşullarından kaynaklanan, tarım rekoltesindeki azalmanın etkisi de oldukça büyüktür. Bütün bu nedenler, bir araya gelince DP'nin hedeflediği liberalizm anlayışı, ekonomide beklenen düzeye ulaşamamıştır. Hükümetin daha önce de, liberalizmin hayata geçirilmesi konusundaki girişimlerinden biri olarak devlete ait fabrikaların özel kişilere devri konusunda bazı ciddi adımlar atılmıştır. Başta Türkiye Sınaî Bankası'nın kurulmasıyla özel sektör özendirilerek bu sektöre kısa

${ }^{35}$ TBMM Zabut Ceridesi, D: 10, c. I, 24.5.1954, s. 59.

${ }_{36}$ TBMM Zabut Ceridesi, D: 10, c. VIII, s. 251; Cem, Çakmak, “1950'li Seçimler ve Demokrat Parti”, Tarih ve Toplum, c. IX, S. 53, (Mayıs 1988), s. 26; Serdar Turgut, Demokrat Parti Döneminde Türkiye Ekonomisi (Ekonomik Kalkınma Süreçleri Üzerine Bir Deneme), Ankara, 1991, s.189. Ahmad, Modern Türkiye'nin Oluşumu, (Çeviri: Yavuz Alogan), Ankara, 1995, s. 165.

1953 Yılı Bütçe Kanunu Tasarısı ve Bütçe Komisyonu Raporu, Ankara, 1953, s. 4; Ali Esen Minkari, 1950-1960 Yıllarında İktisadi Kalkınma ve Gelisme. Ankara, Tarihsiz, s. 19-37; Adnan Menderes' in Konusmalart (TBMM' deki Konussmalarl 29 Mayıs 1950-4 Mart 1954), (Hazırlayan: Mustafa Doğan), c. I, İstanbul, 1957, s. 290; Agâh Oktay Güner, "14 Mayıs 1950 ve 27 Mayıs Dönemeçlerinde Türkiye Ekonomisi”, Ata Dergisi. Selçuk Üniversitesi Atatürk İlkeleri ve İnkılâp Tarihi Araştırma ve Uygulama Merkezi, S. 3, Konya, 1992, s. 72 . 
vadeli krediler verilmesi bu girişimin gelişmesini hızlandırdı. DP'nin özel sektörü desteklemesi, ekonomide tarımla birlikte kısmi olarak dokumacıllk sanayisinin gelişmesini sağlamış ${ }^{38}$ olmasına karşın, 1950'lerde olduğu gibi beklediği yerli yatırımları tam olarak gerçekleştiremedi. Liberalizm söyleminin havada kalması, yatırımların yüzde $40-50$ 'sini devletin yapmak zorunda kalması, Demokratları zor durumda biraktı. ${ }^{39}$

\section{1954-1957 Yılları Arasında Demokrat Parti İktidarı ve Türk Ekonomisi $^{40}$}

1954 'den sonra artık halka somut icraatların gösterilmesi gerekiyordu. Bunun gereği olarak 1955 yılı icraat y1lı olmalıydı. Zira artık DP'nin başarısı, ekonomik atılımlara bağlıydı. Halkın DP'yi desteklemesi için bu gerekliydi. Bu zorunluluk, ekonomik kararların alınması ve uygulanmasında çıkacak bir muhalefetin her şeye rağmen önlenmesi ve tasfiye edilmesi gereğini de doğuruyordu. Zaten DP bu politikasını 1956'da fiili olarak uygulamaya koyacaktır. ${ }^{41}$

Ancak şu da bir gerçektir ki DP hükümetinin bu dönemde izlediği ekonomi politikası önceki yıllardan farklı olmayacaktır. Zaten Menderes'in hükümetin yeni bir programla gelmediğine dair açıklamaları da bunu doğrular niteliktedir. Bu dönemde okunan hükümet programında da tarıma önem verileceği ve bunun sadece tarımsal faaliyetler olarak algılanmaması gerektiğini, hayvancılığın da devlet teşvikiyle yapılacağından söz ediliyordu. Menderes, konuyla ilgili konuşmasında: "Tarım, ulısal ekonomimizin temelidir. Bir yandan ulusumuzun beslenme ve giyinme gereksinimini ve sanayiimizin hammaddesini sağlar ve diğer yandan ihracatımızın da ana kaynağını oluşturur." ${ }^{22}$ der. Menderes konuşmasının başka bir bölümünde ise: "Geçen dönemde kısmen kaldırılmıs olan Hayvan Vergisi'nin kalan kısmını da 1955 yılında kaldırılmasını önermek suretiyle bu ilkel vergiyi bütünüyle tasfiye etmiş olacă̆ız. Veraset ve İtikal Vergisi de ıslah edeceğimiz vergiler arasına alınmış bulunmaktadır" ${ }^{\prime 3}$ Sözleriyle hayvancılığa verilecek devlet desteğinin önemini vurguluyordu. Hükümet programından da anlaşıldığ 1 gibi Menderes, 1954 'ten bu yana ekonomide amaçların iyi belirlenip hedefe doğru gidilmesi için ekonomik faaliyetlerin başarısını hükümet programına bağlıyor ve bu konuda başarılı olabilmenin ön koşulunun koordinasyonlu bir çalışmadan geçtiğine inanıyordu.

38 Güner, a.g.m., s. 10.

39 Baside İcra, Demirkırat Alfabesi (DP Tüzük ve Programu), Ankara, 1992, s. 125; Erik Jan Zürcher, Modernleşen Türkiye'nin Tarihi, İstanbul, 1993, s. 327.

Makale, DP dönemi ekonomi politikalarını 1957'ye kadar incelemesine karşı, DP'nin ekonomi politikalarının etkilerinin daha sonraki yıllara yansıdığını gördügüümüzden 1957 yılı sonrasında da bazı konulara değinilmiştir.

${ }_{41}$ Zarakoğlu, a.g.m., s. 11.

${ }^{42}$ Tutanak Dergisi, D: 10, c. VIII, s. 251; Ayrica bkz. Öztürk, a.g.e., s. 429.

${ }^{43}$ TBMM Zabut Ceridesi, D: 10, c. I, 25.4.1954, s. 30. 
Ancak beklenilenin aksine ekonomide istenilen hedefe ulaşılamadığı gibi aksine tehlike çanları çalmaya başlamıştır. Tehlikenin ilk belirtisi dış ticarete ağırlık veren DP hükümeti, politikasını gerçekleştirmeye yönelik elverişli koşullar, 1954 yılında Kore savaşından sonra ortadan kalkmıştır. Savaş Türkiye'nin geleneksel ihraç maddesi olan tarım ürünlerine olan talebi ve dolayısıyla bunların dünya piyasalarındaki fiyatlarını arttırmışken, savaşın sona ermesi hem talebi hem de fiyatların düşmesi sonucunu doğurmuştur. ${ }^{44}$ Bunun ekonomiye etkisi oldukça ağır olmuştur.

Diğer yandan 1954'den itibaren döviz darboğazı yüzünden DP'nin kuruluşundan itibaren vurguladığı liberalizme kısıtlama getirildi. Özellikle ithalatı kısıtlayıcı önlemler alındı. Şeker ve çimento üretimi için Türkiye'de fabrika kurmaya ve işletmeye olanak hazırlandı. Artık sanayi kesiminde devlet yerini almışırı. ${ }^{45}$ Her ne kadar Türk girişimci sınıfı ve ticari zihniyetin gelişmesini sağlamak ve yatırımları teşvik amacıyla kurulan Sanayi ve Madenler Bakanlığı beklenildiği gibi sonuç getirmemişse de devletin ekonomideki yeri kaçınılmaz hale gelmiştir. Hükümet baştan beri savunduğu liberalizm politikasından bütün bu nedenler yüzünden ödün vermek zorunda kalmıştır.

Ekonomideki bu kötüleşme, siyasal ve sosyal yaşamı da etkiler bir niteliktedir. Her ne kadar Duyun-1 Umumiye borçlarının son ve kesin tasfiyesi 25 Mayıs 1954 de tamamlanmış olsa da ödemeler dengesindeki gecikme enflasyonu da arttırmıştır. Diğer yandan Menderes'in Amerika gezisinde 300 milyon dolarlık borç yerine 30 milyon dolarlık bir hibe ile dönmesi yeni oluşan Türk piyasasının iyice ürkmesine neden oldu. ${ }^{46} \mathrm{Bu}$ aşamadan sonra Türk halkının hiç alışık olmadığı enflasyon gibi kavramlar belirmeye başlayacaktır. Ekonomideki kötü gidiş, DP içinden bazı milletvekillerinin de eleştiri konusu olmuştur. Başta Ahmet Tokuş olmak üzere bu milletvekilleri, hükümetin yaptığı yatırımların fazlalığı yüzünden bu ekonomik sıkıntıların çekildiğini iddia ederek hükümetin bu konudaki plansızlığını eleştiren açıklamalarda bulunmuşlardır. ${ }^{47} 18$ Ocak 1955 'te ise DP grubundan Kenan Akmazlar, Hâluk Timurtaş, Ekrem Cananî ve Feridun Engin, hükümetlerinin ekonomi politikasını eleştiren bir rapor hazırladılar. ${ }^{48}$ Raporda hükümetin ekonomi politikasındaki sorunlar; plansızlık, pahalılık, karaborsacılık ve ithal malları başlıkları altında toplanıyordu. DP içinde benzer eleştiriler 29 Mayıs 1955 'teki Manisa il kongresine de yansımıştır. Ekonomideki kötü gidişin az da olsa farkına varan hükümet ABD'li iktisatçı

44 Turgut, a.g.e., s. 168.

45 Ahmad, The Turkish Experiment in Democracy 1950-1957, s. 138-139.

${ }^{46}$ Mehmet Ali Birand ve diğerleri, Demirkwat (Bir Demokrasinin Doğuşu), İstanbul,

1995, s. 292; Niyazi Berkes, 200 yıldır neden bocaltyoruz? ,Baskı yeri yok,,1965, s. 34.

47 Demokrat Parti Meclis Grubu Müzakere Zabutları, D: X, c. CLX, s. 184-185.

48 Cumhuriyet, 19.1.1955. 
Max Trombug'a bir rapor hazırlattıysa da sonuç alınamamıştır. ${ }^{49}$ Çünkü Metin Toker'in de ifade ettiği gibi ekonomik bunalım, amansız bir servet düşmanlığına dönüşmüştür. ${ }^{50}$

Ekonomideki kötü gidişin önüne geçmek için hükümet bir takım önlemler de almıştır. Bunlar arasında; gümrük vergisinde değer esasına geçilmesi, gümrük tarifelerinin yükseltilmesi, ithal malları fiyat kontrol dairesinin ve en önemlisi de Milli Korunma Kanunu'nun uygulamaya konulmasıdır. Bu yasa piyasaları daha iyi denetleyebilmek stokçuları ve karaborsacıları şiddetle cezalandırmak için 06 Haziran 1956 tarihinde çıkarılan bir yasadır. ${ }^{51}$ Görünüșe bakılırsa Tek parti dönemindeki ekonomik uygulamaları eleştiren hükümet, ekonomideki kötü gidişin çözümünü aynı yöntemle çözmeye çalışmıştır.

Ekonomideki sıkıntılar, bütün bunlara karşın önlenememiş 1956'da artarak devam etmiştir. Kuşkusuz bu sıkıntıların oluşmasında sadece ekonomik nedenler değil iç siyasal gelişmelerin de etkisi oldukça fazladır. 6-7 Eylül olayları iç piyasayı ürküttüğü gibi dış piyasada da hükümetin siyasi ve mali itibarını çok zayıflatmıştır. ${ }^{52}$

Bütün bunlar karşısında Menderes hükümeti, tek başlarına ekonomideki kötü gidişi durduramayacaklarını anladıklarından Avrupa İktisadî İşbirliği Teşkilatı'ndan (OEEC) kendilerine yol göstermesini teknik ve mali yardımda bulunmasını istemiştir..$^{53}$ Örgütün Türkiye için hazırladığı rapor, istikrar paketi olarak Türk yetkililerine sunulmuştur. İstikrar paketinde Türk Lirasının değerinin düşürülerek katlı kur sistemine geçilip ihraç malının cinsine göre prim uygulanması, para arzının sıkı kontrol altına alınması, bütçe denkliği için harcamaların kısıtlanması, yatırım projelerine verimli ve kısa olanlarına öncelik verilmesi gibi önlemler vard1. ${ }^{54}$

49 Halil Cin, "Türk Demokrasi ve Kalkınma Tarihinde 14 Mayıs 1950 ve 27 Mayıs 1960 Dönemeçleri Sempozyumunu açıৎ̧ Konuşması”, Ata Dergisi, Selçuk Üniversitesi Atatürk İlkeleri ve İnkılâp Tarihi Araştırma ve Uygulama Merkezi, S. 3, Konya 1992, s. 12; Cumhuriyet, 15.7.1955.

so Metin Toker, Ismet Paşa ile On Yıl, c. I, Ankara, 1956, s. 105.

5 Yasa, yapılan oylamada 67 red oyuna karşı 321 oyla kabul edildi. Muhalefet bu kanuna olumsuz oy kullandı. Ardından bu yasaya uymayanları hızlı ve etkin bir şekilde cezalandırmak için Milli Korunma Mahkemesi'nin kurulmasını ön gören bir kararname çıkarıldı. Milli Korunma Kanunu için bkz. TBMM Zabıt Ceridesi, D: 10, c. XII, Kısım: 1, s. 222-226; Kararname için bkz. Demokrat Parti Meclis Grubu Müzakere Zabutları, D: 10, c. CLLLIV, s. 7-10.

Albayrak, a.g.e.s. 357-358; Hikmet Bila, Sosyal Demokrat Süreç Içinde CHP ve Sonrast Baskı yeri yok, 1987, s. 224

53 Fahri Aral, "Hayrettin Ekmenle DP Üzerine" Tarih ve Toplum, c. IX, S. 53, (Mayıs 1988), s. 32; Boratav, "DP Döneminde Ekonomi", Tarih ve Toplum, c. IX, S. 53, (Mayis 1988), 36

Tokgöz, a.g.m., s. 334 
Hükümet'in bu istikrar paketini yürürlüğe koyması karşılığında Avrupa İktisadi İşbirliği Teşkilatı da, 400 milyon dolarlık Türkiye'den alacağ1 borcu ertelemiş; 359 milyon dolar yeni kredi vermiştir. ${ }^{55}$ Böylelikle 1958 yılında Türkiye Batılı dostlarının yardımıyla ekonomik sıkıntılarını çözebilmek için önemli bir adım atmış bulunuyordu. Bütün bu gelişmeler, DP'nin amaçladığı ekonomi politikanın yanlış olduğunu ortaya koyuyordu. ${ }^{56}$

\section{A) DP Dönemi Gelir ve Devlet Harcamalart}

Tek parti döneminde olduğu gibi DP iktidarı döneminde de, tarımın ekonomideki payı büyüktür. Fakat bu pay, DP iktidarının sonlarına doğru azalmaya başlayacaktır. Tarım gelirleri 1950 yılında \% 50 iken 1955 yılında \% 46'ya inmiş; faal nüfus içinde tarımla uğraşanların sayısında da bir azalma yaşanmıștır. 1950'lerde tarımla uğraşan nüfus \% 84,1 iken 1955'den sonra bu oran $\% 76,8$ e düşmüştür. Buna karşllık sanayi gelirleri yükseldiği gibi, sanayideki faal nüfus miktarı da artmıştır. Faal nüfusun tarımdan sanayiye hızlı geçişi, sanayi gelirlerinin artışını sağladığı gibi milli gelirde de hızlı bir yükselişe neden olmuştur. Örneğin, 1950'lerde sanayideki reel gelir \% 61,4 iken bu yıldan sonra yıllık artış hızı \% 10,2'ye yükselmiştir. 1950 yılında sanayi gelirleri o yıl milli gelirinin \% 11,1'ini teşkil ederken bu oran 1956'da \% 12,3'e yükselmiştir. Buna bağlı olarak da sanayide çalışan faal nüfus oranı 1950'de \% 4,1 iken 1956 'da \% 6,8 oranında bir artış göstermiştir. ${ }^{57}$

Tablo 1: Gelir ve Devlet Harcamaları (1950-1953) (Milyon TL) $)^{58}$

\begin{tabular}{||c|c|c|c|l|c|c|c||}
\hline Yillar & Gelirler & Harcamalar & Açık & $\begin{array}{l}\text { Açık } \\
\text { Oranı } \\
(\%)\end{array}$ & $\begin{array}{l}\text { Özel } \\
\text { Gelirler }\end{array}$ & $\begin{array}{l}\text { T. } \\
\text { Açık }\end{array}$ & $\begin{array}{c}\text { T. Açık } \\
\text { Oranı (\%) }\end{array}$ \\
\hline 1950 & 1.670 & 1.826 & 156 & 9,3 & 108 & 48 & 2,80 \\
\hline 1951 & 1.821 & 2.023 & 202 & 11,1 & 257 & 55 & 2,00 \\
\hline 1952 & 2.336 & 2.587 & 251 & 10,7 & 237 & 14 & 0,56 \\
\hline 1953 & 2.250 & 2.511 & 261 & 11,6 & 239 & 22 & 0,97 \\
\hline Toplam & 8.077 & 8.947 & 870 & 42,7 & 841 & 138 & 6,33 \\
\hline
\end{tabular}

55 Döviz kurundaki yükseliş ve alınan borçların verimli kullanılmaması yüzünden alınan borçlar erimiş Türk ekonomisi için uzun vadede faydalı olamamıştır. Akis, Yıl: $4, \mathrm{c}$. X, S. 159 , Ankara, 1957, s. 15.

S6 Albayrak, a.g.m., s. 362; Cumhuriyet, 01 Şubat 1956, s. 5.
${ }_{57} 1954$ Yll Bütce Kanunu Layihast, Ankara, 1954, s. 3-64; 1958 Yll B Bütçe Layihast ve Bütçe Encümeni Mazbatası, Ankara, 1958, s. 334-347 (Bundan sonraki dipnotlarda 1958 Ytlt Bütçe ...s şeklinde kısaltılmış olarak gösterilecektir.); Minkari, a.g.e., s. 15-26.

I Bes Yıllık Kalkınma Planı, Ankara, 1963, s. 17; Bilge Aloba Köksal-A. Rasih İlkin, Türkiye'de Iktisadi Politikanın Gelişimi (1923-1973), İstanbul, 1973, s. 47; Güner, a.g.m., s. 76 . 
Tablo 2: Gelir ve Devlet Harcamaları (1954-1957) (Milyon TL)

\begin{tabular}{||c|c|c|r|r|r|r|c||}
\hline \hline Yillar & Gelirler & Harcamalar & Açık & $\begin{array}{l}\text { Açık } \\
\text { Oranı } \\
(\%)\end{array}$ & $\begin{array}{l}\text { Özel } \\
\text { Gelirler }\end{array}$ & $\begin{array}{l}\text { T. } \\
\text { Açik }\end{array}$ & $\begin{array}{l}\text { T. Açık } \\
\text { Oranı } \\
(\%)\end{array}$ \\
\hline 1954 & 2.300 & 2.662 & 362 & 15,70 & 187 & 173 & 7,50 \\
\hline 1955 & 2.694 & 3.394 & 700 & 25,90 & 539 & 160 & 5,90 \\
\hline 1956 & 3.260 & 3.771 & 511 & 15,60 & 528 & 182 & 5,60 \\
\hline 1957 & 3.948 & 4.302 & 354 & 8,90 & 157 & 196 & 6,60 \\
\hline 1958 & 4.548 & 5.136 & 588 & 12,90 & 432 & 155 & 3,40 \\
\hline Toplam & 16.750 & 19.265 & 2.515 & 79,00 & 1.843 & 866 & 29 \\
\hline
\end{tabular}

Tablo 1 de görüldügü gibi sanayideki hızlı gelişme gelir ve gider dengesi arasındaki açığı da kapatmış buna bağlı olarak da bütçedeki açık oranı azaltılmıştır. Gelir ve gider arasındaki açığın kapanması özellikle 1952 yılından sonra hız kazanmıştır bunda Türkiye'nin NATO'ya girişinin etkisi büyüktür. Zira Türkiye'nin NATO'ya girişiyle savunmaya ayrılan pay, yatırımlara aktarılmıştır. Ekonomide dişa bağımlılık artmasına karşın 1955'ten sonra kısa süreli belli bir düzelme de yaşanmıştır. Fakat Ekonomideki bu iyileşme dönemi aynı zamanda nüfustaki hızlı artış ve kırsal alandan kente göçün de hızlı olduğu bir dönemdir. Toplam nüfus artışı 1938'lerden 1950'lere kadar \% 23,1 iken 1956 yılından sonra 1950 yılına kıyasla \% 23, 4 oranında bir artış göstermiştir. Ekonomideki hızlı büyümeye karşın nüfus artışı ve göçle birlikte reel milli gelirdeki düzey hemen hemen çok fazla değişmemiştir. 1938 'de kişi başına düssen gelir 432 lira iken 1954'te 434 lira 1956 yılında 536 liraya yükselmiştir. ${ }^{60}$

DP iktidarı döneminde sanayileşme çabaları ile birlikte dışa bağımlılık iyice artmıştır. Zira bu dönemde karşılaşılan yatırım ve yedek parça sorunu o günün de ekonomik sorunları arasındaydı. Ticaret hacminin tarım ürünleri aleyhine gelişmesi, 1955 'lerden sonra ithalatta sıkıntıların doğmasına neden oldu. Bu güçlükler, devlet sektöründen çok özel sektörü etkiledi. Artık özel sektör rekabet gücünü kazanmadan yitirme tehlikesiyle karşı karşıya kalmıştı.

IV) YATIRIMLAR, DEVLET BÜTÇESİ VE DIŞ TICARET DURUMU

\section{A)Yaturumlar}

DP iktidarı döneminde, yatırım miktarı ve gayrı safi ulusal gelirden yatırımlara ayrılan pay, bu dönemde düzenli bir biçimde artmıştır. Ortalama artış oranı \% 13,5'tur. Fakat devlet giderleri de buna göre artmıştır. Devlet yatırım giderlerinin 1953 'ten sonraki artışında açık finansman en çok başvurulan yol olduğu görülür. Bu yıllarda söz edildiği gibi ekonominin temeli sayılan tarıma büyük önem verilmesine karşın kötü hava koşulları ve

I. Bes Ylllık Kalkanma Planı, s. 17; Güner, a.g m., s. 76.

60 1958 Ytlı Bütçe..., s. 334. 
Kore Savaşı'nın son bulmasıyla tarım ürünlerine olan talebin azalması Türkiye'yi oldukça etkilemiştir. Bu durum, dış ticaret dengesini de çok sarsmıştır. Her ne kadar iktidar tablo 1'de de görüldüğü gibi, 1952'deki ithalat patlamasını 1954 yıllarında kapatsa da yatırımların verimli duruma dönüştürülememesi yüzünden ekonomik istikrar sağlansa da bütçe açığı devam etmiştir. Bu da enflasyon sorununu birlikte getirmiş, tüketim hızla artarken üretimdeki artış hızı yavaşlamıştır. ${ }^{61}$ Dış ticaret açı̆̆ı da ekonomide aşılması gereken sorunlar olmasına karşın tablo l'de de görüldügüu gibi bu açık kapatılamamıştır.

\section{B) Bütçe}

Liberal düşüncenin temsilcisi olarak iktidara gelen Demokratların bütçenin hazırlanışı ve bütçe oranının belirlenmesinde neredeyse bu günkü iktidarları temsil eder niteliktedir. Zira sosyal güvenlik, sağlık ve eğitim gibi konulara son zamanlarda ağırlık verilse de yapısal reformlar için gerekli bütçe ayrılmamıştır. Bunun yerine savunma harcamalarına daha büyük öncelik verilmesi günümüz iktidarlarını anlatır gibidir. İktidarların genel söylemi haline gelen Türkiye'nin jeopolitik konumundan dolayı savunma gücüne önem verilmesi gereği bu günün hükümetlerinin de temel gerekçeleri arasındadır.

Fakat tablo 3 ve 4 de belirgin şekilde görüldügü gibi 1953 'te savunmaya büyük pay ayrılmasına rağmen, 1954 'ten sonra bunun yerini ekonomik kalkınma alacaktır. Bunun nedenleri arasında Türkiye'nin NATO'ya girişiyle birlikte savunmada bir rahatlama döneminin başlamasından kaynaklanır. Zaten 1947'den sonra Türkiye Marshall planı çerçevesinde aldığı dış yardımlar sayesinde önceki dönemlere göre savunmasında büyük bir rahatlama yaşamıştır.

Tablo 3: 1950-1954 Yılları Arasında Bütçenin Genel Dağılımı ${ }^{62}$

\begin{tabular}{||l|l|l|l|l|l||}
\hline \hline & 1950 & 1951 & 1952 & 1953 & Toplam \\
\hline Sağlık & 59.748 .278 & 66.987 .125 & 84.995 .725 & 115.747 .697 & 327.478 .825 \\
\hline Eğitim & 193.426 .741 & 205.643 .875 & 221.452 .582 & 266.965 .233 & 887.488 .431 \\
\hline Sosval Güvenlik & 123.047 .484 & 139.631 .831 & 148.816 .104 & 166.331 .148 & 577.826 .567 \\
\hline E. Kalkınma & 289.822 .496 & 320.486 .008 & 382.805 .900 & 520.671 .534 & 1.513 .785 .938 \\
\hline Savunma & 520.912 .611 & 529.776 .392 & 541.919 .236 & 634.999 .673 & 2.227 .607 .912 \\
\hline Borç Ödeme & 98.393 .857 & 105.165 .488 & 114.888 .697 & 126.473 .229 & 444.921 .271 \\
\hline Genel Idare & 201.857 .096 & 212.068 .018 & 256.047 .157 & 296.318 .222 & 966.290 .493 \\
\hline Toplam & $\mathbf{1 . 4 8 7 . 2 0 8 . 5 6 3}$ & $\mathbf{1 . 5 7 9 . 7 5 8 . 7 3 7}$ & $\mathbf{1 . 7 5 0 . 9 2 5 . 4 0 1}$ & $\mathbf{2 . 1 2 7 . 5 0 6 . 7 3 6}$ & $\mathbf{6 . 9 4 5 . 3 9 9 . 4 3 7}$ \\
\hline
\end{tabular}

G1 Giritli, a.g.e., s. 83; Ahmad, The Turkish Experiment in Democracy 1950-1957, s.

1958 Yıll Bütçe..., s. 64. 
Tablo 4: 1954-1957 Yılları Arasında Bütçenin Genel Dağılımı ${ }^{63}$

\begin{tabular}{||l|l|l|l|l|l||}
\hline & 1954 & 1955 & 1956 & 1957 & TOPLAM \\
\hline Să̆hık & 126.358 .957 & 148.957 .081 & 161.886 .496 & 192.655 .526 & 629.858 .060 \\
\hline Eğitim & 310.856 .724 & 426.879 .619 & 493.030 .575 & 579.331 .137 & 1.810 .098 .055 \\
\hline SosyalGüvenlik & 167.053 .020 & 192.763 .374 & 224.502 .504 & 235.932 .112 & 820.251 .010 \\
\hline E. Kalkınma & 556.775 .006 & 815.599 .468 & 925.817 .547 & 1.236 .072 .728 & 3.534 .264 .749 \\
\hline Savunma & 663.861 .440 & 804.562 .296 & 873.144 .952 & 1.053 .914 .645 & 3.395 .483 .333 \\
\hline Burç Ödeme & 126.475 .447 & 131.491 .237 & 137.580 .668 & 157.244 .552 & 552.791 .904 \\
\hline Genel İdare & 337.094 .406 & 420.474 .203 & 509.011 .410 & 551.522 .159 & 1.818 .102 .178 \\
\hline Toplam & $\mathbf{2 . 2 8 8 . 4 7 5 . 0 0 0}$ & $\mathbf{2 . 9 4 0 . 7 2 7 . 2 7 8}$ & $\mathbf{3 . 3 2 4 . 9 7 4 . 1 5 2}$ & $\mathbf{4 . 0 0 6 . 6 7 2 . 8 5 9}$ & $\mathbf{1 2 . 5 6 0 . 8 4 9 . 2 8 9}$ \\
\hline \hline
\end{tabular}

1954'ten sonra yabancı sermayenin Türk ekonomisine girişiyle ekonomik kalkınma hız kazanmıştır. Bütçenin hazırlanışında da bu durum göz önüne alınarak ekonomik kalkınmaya ayrılan pay savunmaya ayrılan payı geçmiştir. Bu durum yabancı sermayeyi Türkiye'ye çekmenin yanı sıra yerli sanayiyi de hızlandırmak ve Türk girişimcilerinin yatırım yapmalarını sağlamak için planlanmış politikanın ürünüdür. Fakat DP iktidarı, bir süre sonra ekonomide aldığı bu radikal kararlardan geri adım atmak zorunda kaldı. Çünkü gerek ana muhalefet partisi CHP'nin "devleti satıyorlar" söylemi ile kamuoyunu etkilemesi ve gerekse ekonomide dışa bağımlılı̆̆ın gittikçe artması DP İktidarını geri adım atmaya itmiştir. ${ }^{64}$

Bütçenin genel dağılımına bakıldığında genel bir dengenin egemen olduğu görülür. DP iktidarının en güçlü olduğu yıllarda, tablo 4'deki verileri yüzdelik dilimler halinde ele alır yorumlarsak, 1954'ten sonra artan dışa bağımlılık 1957 'den sonra da devam etmiştir. Bütçenin genel dağılımı tablo 4'de de görüldügüü gibi, 1954'te en büyük pay, \% 29'luk bir oranla savunmaya ayrılmıştır. Savunmaya ayrılan bu oran 1955 'te \% 27,$3 ; 1956$ 'da $\%$ 26,2; 1957 'de \% 26,3 olarak belirlenmiştir. Bütçede 1957'den sonra en fazla pay, ekonomik kalkınmaya ayrılmıştır. Ekonomik kalkınmaya ayrılan pay, 1954 'te $\% 24,3 ; 1955$ 'te $\% 27,7 ; 1956$ 'da $\% 27,8 ; 1957$ 'de ise $\% 30,8$ olarak gerçekleşmiştir. Toplam oranda ekonomik kalkınma, savunmaya ayrılan payı geçmiştir. Üçüncü sırada genel idare yer almaktadır. Genel idarenin yıllara göre dağılımı ise: 1954'te \% 14,7; 1955'te 14,3; 1956'da 15,$3 ; 1957$ 'de 13,8 olarak gerçekleşmiştir. Bütçede dördüncü sırada yer alan eğitime ayrılan pay oranı 1954 'te $\% 13,6 ; 1955$ 'te $\% 14,5 ; 1956$ 'da $\% 14,8$; 1957 'de \% 13,7 olarak belirlenmiştir. Beşinci sırada ise sağlığa ayrılan pay yer almaktadır. Sağlığa ayrılan pay, 1954 'te $\% 5,5 ; 1955$ 'te \% 5,6; 1956'da $\% 4,8 ; 1957$ 'de \% 4,8 olarak gerçekleşmiştir. Bütçede son sırayı borç ödeme oluşturur. Borç ödemenin yıllara göre dağılımı ise şöyledir: 1954 'te \% 5,5; 1955 'te \% 4,8; 1956 'da \% 4,1; 1957 'de \% 3,9 olarak gerçekleşmiştir.

Oranlardan da anlaşılacağı üzere DP iktidarı, 1954'ten sonraki yılı ekonomik hamle yıllı olarak görmüş ve bütçeyi de buna göre hazırlamıştır.

1958 Yllt Bütçe..., s. 68

${ }^{4}$ Turgut, a.g.e., s. 168; Güner, a.g.m., s. 72-73. 
Bunda sözedildiği gibi DP'ye oy veren kitlelerin artık partiden icraat beklentileri önemli rol oynamıştır. DP'nin gelecek seçimdeki başarısı ekonomiye entegre olmuş gibidir.

\section{C) Dıș Ticaret ve Ekonomide ABD Etkisi}

DP iktidarları, ekonomik başarının sağlanmasında çözümü dış kredi almada buldular. Bu olaylardan sonraki gelişmeler gösteriyor ki Menderes hükümetleri döneminde dış kaynaklara bağımlılık iyice artmış, değişen ekonomi politika ve dış krediler, önde gelen müttefiki Amerikan yardımı ile yapılır duruma gelmişsir. Türkiye'nin dış yardım arayışı, DP iktidarından önceki tarihe dayanır. İlk olarak, Truman Doktrini ile ABD'nin, Yunanistan'ın yanında Türkiye'yi de programa almasıyla başlamıştır. Bu durum, Amerikan çıkarı yanında 1947'lerde Sovyet tehditleriyle çevrilmiş olan Türkiye'nin de işine geliyordu. Askeri ve ekonomik gücü zayıf olan Türkiye, bu fırsatı iyi değerlendirdiği takdirde bölge devletleri içerisinde güçlü bir hale geleceğini umuyordu. Truman Doktrini Türk dış politikasının da değişmesine yol açmış olması bakımından önemlidir. Bunun ilk belirtisi, daha önce bağımsız bir Arap devletinin kurulmasını savunan Türkiye, şimdi kuruluşundan dokuz ay sonra İsrail devletini resmen tanıyor ve Yahudi asıllı vatandaşların İsrail'e göç etmeleri için gerekli izni veriyordu. ${ }^{65}$

Truman Doktrini, Türkiye'ye sadece ekonomik yardım sözü vermiyor, bir takım siyasal yükümlülükler de getiriyordu. Çünkü Doktrin, Türk dış politikasını sınırlayan bir takım maddeler içeriyordu. Bunlardan en önemlisi 24. Maddedir. Gerçekten Birleşik Amerika, bu anlaşmanın imzalanmasından on yedi yıl sonra, 1964 Haziranında Türkiye'nin Kıbrıs'a yapmayı düşündügüü silahlı bir müdahaleyi sınırlayan maddesi şöyledir: Türkiye Hükümeti, Birleşik Devletler Hükümeti'nin muvafakati olmadan, bu neviden hiçbir madde veya malumatın mülkiyet ve zilyetliğini devredemeyeceği gibi, aynı muvafakat olmadan Türkiye Hükümeti'nin subay, memur veya ajanı sıfatı haiz bulunmayan bir kimse tarafindan bu maddelerin ve bu malûmatın gayeden başka bir gayeye kullanılmasına müsaade etmeyecektir. ${ }^{66} \mathrm{Bu}$ madde Türkiye'ye yapılacak yardımların karşısında belli bir sorumluluk yüklüyordu. Bu anlamda Türkiye'yi, siyasi ekonomik ve askeri bakımdan Birleşik Devletlere daha bağımlı hale getiriyordu. ${ }^{67}$

Türk-Amerikan ilişkilerinin gelişmesini sağlayan diğer bir yardım planı ise, Marshall yardım planıdır. Bu planın amaçları ve gerekçeleri bakımından

65 Hüseyin Bağcı, Demokrat Parti Dönemi Dış Politikası, Ankara, 1990, s. 13; Ayrıca Bkz. Harry S. Truman, Memoirs, Vol. I, Doubleday and Company, New York, 1955.

${ }^{66}$ Gönlübol ve Diğerleri, Olaylarla Türk dıs Politikası, Ankara, 1974, s. 233.

${ }^{6}$ Aynı zamanda Truman Doktrini ile ABD, Türkiye gibi devletlerin korumacı liderliğini üslenmiş oluyordu. Yusuf Sarınay, Türkiye'nin Bat İttifakına Yönelişi ve NATO'ya Girişi, Ankara, 1988, s. 66; Türkkaya Ataöv, "Doğu Avrupa'nın Sosyalistleşmesinden Truman Doktrini'ne Kadar Soğuk Harp", S.B.F.D., c. XXIII, No. 2, Ankara, (Haziran 1968). 
Truman Doktrini ile büyük benzerlikler gösterir. Bu anlamda Truman Doktrini, Marshall Planı'nın ön hazırlığı gibidir. Fakat görünüşte benzerlikler olsa da amaçta bir takım farklılıklar vardır. Bu anlamda Truman Doktrini'nin amacı, Sovyet yayılmasını önlemeye dönük bir program olduğu halde, Marshall Planı daha çok Avrupa ülkelerinin ekonomik kalkınmasını sağlayarak komünist ideolojinin bu ülkelere sızmasını önlemek olmuştur.

Tablo 5: Dis Ticaret Durumu (1950-1953) (Milyon TL) ${ }^{68}$

\begin{tabular}{||c|c|c|c||}
\hline Yıllar & Ithalat & Ihracat & Dis Ticaret Acı̆̆ı \\
\hline 1950 & 286 & 263 & 23 \\
\hline 1951 & 402 & 314 & 88 \\
\hline 1952 & 556 & 363 & 193 \\
\hline 1953 & 533 & 396 & 137 \\
\hline Toplam & 1777 & 1336 & 441 \\
\hline
\end{tabular}

Tablo 6: Dis Ticaret Durumu (1954-1958) $\left(\right.$ Milyon TL) ${ }^{\oplus}$

\begin{tabular}{||c|c|c|c||}
\hline Yıllar & İthalat & Ihracat & Dis Ticaret Acı̆̆ \\
\hline 1954 & 478 & 335 & 143 \\
\hline 1955 & 498 & 313 & 185 \\
\hline 1956 & 407 & 305 & 102 \\
\hline 1957 & 397 & 345 & 52 \\
\hline 1958 & 315 & 247 & 68 \\
\hline Toplam & 2095 & 1545 & 550 \\
\hline
\end{tabular}

Tablo 5'de görüldüğ̈ gibi 1950 yılında ithalat-ihracat arasındaki açık 23 milyon TL iken bu rakam 1950'den itibaren hızla artmıştır. 1952'de ithalatihracat dengesi DP hükümetlerinin iktidar olduğu dönemler içerisinde en yüksek düzeyine çıkmıştır. Bunda sözedildiği gibi Kore Savaşı'ndan sonra tarım ürünlerine olan talebin azalışı ile kötü hava koşulları nedeniyle tarım rekoltesindeki düşüşün çok büyük etkisi vardır.

NATO'ya girişten sonra Türkiye'nin savunmaya ayırdığı bütçesi yerini yatırımlara bıraksa da bu yatırımlar daha çok başta ABD olmak üzere yabancı patentliydi. ${ }^{70}$ Fakat 1955 'ler ve sonrasında alınan dış kredilere rağmen ekonomideki istikrarsızlık ve dış ticaret açı̆̆ı önlenememiştir. Dışa bağımlılık, döviz kurlarındaki yükselme DP hükümetini iç kaynak arayışına itmiştir. Bu nedenlerle bu dönemde yoğun olarak görüleceği gibi yabancıları teşvik edici bir takım yasalarla bunu gerçekleştirmeye çalışması dönemin belli başlı özelliklerindendir. 1955'lerdeki ekonomik belirsizlik, politikayı da etkilemiş ve

${ }_{69}^{68}$ DIE Türkiye Ístatistik Yıllığı, 1981 Özel Sayı, s. 323; Güner, a.g m., s. 75 .
DIE Türkiye'de Toplumsal ve Ekonomik Gelismenin 50 Yılı, s. 395; Bilge Aloba Köksal- A. Rasih İlkin, Türkiye'de Íktisadi Politikanın Gelişimi (1923-1973), İstanbul, 1973, s. 35 , Güner, a.g.m., s. 75 .

Sarınay, a.g.e, s. 66; Türkkaya Ataöv, "Doğu Avrupa'nın Sosyalleşmesinden Truman Doktrini'ne Kadar Soğuk Harp", S.B.F.D., c. XXIII, No. 2, Ankara, (Haziran 1968); Giritli, a.g.e., s. 83. 
bu dönemden sonra iktidar olan DP'de bir takım çözülmeleri de birlikte getirmiş̧tir. Ekonomideki olumsuzluğun etkisi, bununla da kalmamış DP iktidarı iç politika da daha sert bir çizgi izlemeye başlamıştır.

Diğer yandan bu dönemde ABD ve Sovyetler arasındaki soğuk savaş, Türk ekonomisini ABD'ye daha da bağımlı duruma getirdi. Ayrıca ABD'nin Ortadoğu'da Mısır'ı işgal eden İsrail'e karşı sert tutumunun ardından gelişmeler Türkiye'yi daha içine kapanık bir duruma getirecektir. Ortadoğu'da Türk ekonomisini ve politikasını kısıtlayan sadece bu olayla sınırlı değildir. Aynı zamanda ulusal bağımsızlık sürecinde Cezayir'e çekimser oy verilmesi, İran'da Musaddık'a karşı Şah'ın desteklenmesi gibi konular da Türkiye'yi zor durumda bırakmıştır. Bütün bu gelişmeler Türk politikasını etkilediği gibi ekonomiyi de derinden etkilemiştir.

DP'nin ekonomi politikası bu dönemde dış politikayla karışmış gibidir. Bunun belirtisi olarak Ankara'nın daha çok ekonomi ve Sovyet tehlikesine karşı benimsediği Eisenhower Doktrini'nin benimsenmesinin ardından ${ }^{71}$ Bağdat Paktı toplantısında masaya yatırılan konuların başında ekonomik konular geliyordu. Sonradan bu RCD (Regional Cooperation for Development- Kalkınma için Bölgesel İşbirliği Teşkilatı) olarak ortaya çıkıyordu. ${ }^{72}$

\section{D) Dış Ticaret Antlaşmaları}

Demokratlar iş başına geldikten sonra sözedildiği gibi liberalizm ve yabancı yatırımlara oldukça önem vermişlerdir. Bunun gereği olarak uluslararası antlaşmaların çoğu ticaret antlaşmasına yöneliktir. 1950-1957 yılları arasında Demokratların iktidarının doruk noktası olduğu dönemde bile çoğu tarımla ilgili ticaret antlaşması yapılmıştır. DP'nin dış ticarette sayı olarak en fazla antlaşma yaptığı devlet ABD'dir. ABD ile yapılan ticari antlaşmaların çoğu tarımla ilgilidir. Daha çok Türkiye'nin tahıl satışını öngören antlaşmalardır. Bu ülke ile yapılan ilk iki antlaşma yatırım, diğeri bankacılıkla ilgilidir. Diğer antlaşmalar ise savunma amaçlı olup bu ülkeden alınacak teknik yardımla ilgilidir. ${ }^{73}$

71 Eisenhower Doktrini, Ortadoğu'ya yapılan dolaylı saldırının bir sonucudur. Bundan sonra ABD ve Sovyetler Birliği Ortadogu yu bir güç dengesi alanı olarak kullanacaklardır. Ortadoğu devletleri açısından Eisenhower Doktrini Mısır'daki radikal başkan Nasır'ın yaptığı darbenin ardından bölgede darbelerin ve iç kargaşanın yaşandığı alan haline gelecektir. Her yeni darbeyle birlikte gelenekçi rejimler ve monarşiler ABD ile biraz daha bütünleşirken, yeni radikal yönetimlerin Sovyetler'den ekonomik ve askeri yardım sağlamaları, uluslararası komünizmin yayılması diye değerlendirilecektir. Gevgilili, a.g.e., s. 92.

72 Sükrü Kaya, "Eisenhower'in Ekonomi Politikasi" Hürriyet, 15 Ocak 1955, s. 2; Feroz ve Bedia Turgay Ahmad, Türkiye'de Çok Partili Politikanın Açıklamalı Kronolojisi (1945-1971), İstanbul, 1971, s. 158.

${ }^{73}$ Düstur. III. Tertip, c. XXXVII, Kanun No: 6788, s. 1926; Düstur, III. Tertip, c. XXXVII, Kanun No: 6791, s. 1957; Düstur, III. Tertip, c. XXXVII, Kanun No: 6849; TBMM Kavanin Mecmuası, Devre: X, Içctima: 2, c. XXXVIII-1, s. 1492. 
Türk-ABD yakınlaşması, ABD açısından Türkiye'nin Ortadoğu'nun vazgeçilmez bir ülkesi olarak görmesinde etkili olmuştur. Türkiye açısından ise bu yakınlaşmanın önemi, İkinci Dünya Savaşı'ndan sonra güttüğü yayılmacı politikası ve buna bağlı olarak Komünizm tehlikesini önlemenin yollarını aramasının bir sonucudur. ABD, özellikle Sovyet yayılmasına karşı Ortadoğu ve Balkanlarda bir takım stratejiler bulma çabasına girişmiştir. Bu girişim, ABD'ye müttefik bulmada öncelikle ekonomik bağlarla oluşan bir siyasi yapılanma, ardından askerî ve diplomatik bağlarla oluşan bir bloklaşmanın sonucudur.

Demokratların ticaret antlaşmaları bakımından önem verdiği diğer bir ülke Yugoslavya Federatif Halk Cumhuriyetidir. Bu devletle ilk olarak 09 Temmuz 1956'da Buğday ve pamuk ticaretiyle ilgili bir antlaşma yapıİmıştır. $\mathrm{Bu}$ ülkeyle yapılan diğer iki antlaşma ise, mal değişimi ile Türk mal, hak ve menfaatlerinin tazmini ile ilgili kanundur. ${ }^{74}$

DP, İtalya, Japonya ve Almanya gibi devletlerle de ticaret antlaşmaları yapmıştır. İtalya ile yapılan antlaşmadan biri ekonomik ve teknik işbirliği antlaşmasıdır. Diğeri ise tarımla, özellikle buğday tarımı ile ilgilidir. Almanya ile yapılan antlaşmalardan biri Batı Almanya ile yapılmıştır. Batı Almanya ile yapılan bu antlaşma, Türk sanayisi için teknik destekli sanayi antlaşması ve bu ülkeyle ticaret sonrası Türk hükümetinin yapacağı ödeme planıyla ilgili olan antlaşmadır. ${ }^{75}$ Diğeri ise Almanya'nın tarımı özellikle hayvancılığı geliştirmek için örnek çiftlikler yapılmasına ilişkin yapılan antlaşmadır. ${ }^{76}$

DP, bazı devletlerle de daha önce yapılmış olan anlaşmaların yenilensine yönelik ek protokol antlaşmaları da yapmıştır. Bu anlaşmalardan, Fransa ile 1946 'da yapılan ticaret antlaşmasına ek protokol antlaşması ${ }^{77}$, Macarlarla 1954 'te yapılan antlaşmaya ek protokol antlaşması, Polonya ile buğday satışına ilişkin ticaret antlaşması Hollanda ile ticaretin geliştirilmesine yönelik iyi niyet protokolüdür. Bir diğer antlaşma ise, Avrupa para antlaşmasının geçici uygulamasına ilişkin olup, Belçika ile hava ulaştırması konusunda yapılan antlaşmadır. $^{78}$

DP hükümetlerinin Ortadoğu ve Müslüman ülkelerle yaptığı antlaşmalar çok sınırlı kalmıştır. Mısır ile ticaret ve ödeme planı ile ilgili antlaşma ${ }^{79}$, Pakistan ile hava servislerine ait antlaşmanın onaylanması, Suriye ile sınırlı

74 Düstur, III. Tertip, c. XXXVII, Kanun No: 6787, s. 1924; TBMM Kavanin Mecmuası, Devre: X, İctima: 2, c. XXXVIII-1, s. 1129.

75 Düstur, III. Tertip, c. XXXVIII, Kanun No: 6963, s. 1218; TBMM Kavanin Mecmuast, Devre: X, İctima: 3, c. XXXIX, s. 836.

76 Düstur, III. Tertip, c. XXXVII, Kanun No: 6645, s. 281.

7 Düstur, III. Tertip, c. XXXVI, Kanun No: 6521, s. 1059

78 Distur. III. Tertip, c. XXXVIII, Kanun No: 6970, s. 1261; TBMM Kavanin Mecmuası, Devre: X, İctima: 3, c. XXXIX, s. 868.

79 Düstur. III. Tertip, c. XXXVI, Kanun No: 6523, s. 1084. 
ticaret antlaşması ${ }^{80}$, İran ile ticari ödeme planı ve bununla ilgili protokol imzalanmıștır. ${ }^{81}$ Demokratları bu politikaya iten nedenler arasında bu devletlerin iç rejimlerinde sorunlar olması ve Arap-İsrail Savaşı'nda Türkiye'nin tarafsız görünmesine karşın Batılıların yanında yer almak istemesinden kaynaklanır. Bunda Sovyet tehlikesinde ABD ve Batılıların desteğini yitirmeme düşüncesi de vardır.

Sözü edilen devletler dışında uluslararası bir örgüt olan Birleşmiş Milletler ile de birçok ticari antlaşmalar yapılmışır. Bu yıllar arasında BM ile yapılan ticaret antlaşmasının sayısı 29'dur. Bu antlaşmaların çoğu eski protokol ve antlaşmaların onayı niteliğindedir. ${ }^{82}$ Birleşmiş Milletlerle 25 Mart 1955 'te yapılan antlaşma, sanayi standardizasyonu için teknik destek almak için uzman getirilmesi ile ilgilidir..Bu desteğin çoğu sanayinin geliştirilmesi için alınmıştır. BM'den teknik destek alma ihtiyacı 1956'ya kadar sürmüştür. $\mathrm{Bu}$ yıldan sonra yapılan antlaşma, gıda ve tarım organizasyonun geliştirilmesi ve yapılan işbirliği ile ilgili antlaşmadır. 1954-1957 yılları arasında yapılan ticari antlaşmaların üçü tarım ve tarımın modernizasyonu için yapılmıştır. Bu antlaşmalar ek protokol olsa bile BM Demokratların hem ticari danı̧̧manı hem de teknik destek alabileceği bir örgüt olarak görülmüştür. ${ }^{83}$

Görüldügü gibi DP hükümetleri, bu dönem de ticari antlaşmalarının çoğunu Avrupa ülkeleri ve ABD ile yapmıştır. Menderes iktidarı, Doğu ve Batı bloğunun güç dengesini görmüş ve Ortadoğu'da çıkan güç boşluğunu Türkiye'nin hedeflerine uygun bir şekilde kullanılması yönünde dış politika hedefini çizmişti. Diğer yandan Türkiye NATO'nun bir üyesi olarak elde ettiği bu savunma ve işbirliği anlaşmasıyla Ortadoğu'da bu konumunu iyi değerlendirmek istiyordu. Türkiye bu bakımdan kendini, Ortadoğu ile Batı devletleri arasında kurulabilecek siyasi, askeri ve ekonomik işbirliğinde bir köprü olacağını düşünüyordu.

\section{SONUÇ}

Dörtlü Takrirden iktidar basamağına kadar yükselen Demokratların, Türk ekonomisinde gerçekleştirdikleri radikal değişikler ekonomiye olumlu katkısı olduğu gibi olumsuz etkileri de olmuştur. Bu anlamda İkinci Dünya

${ }^{80}$ Düstur. III. Tertip, c. XXXVIII, Kanun No: 6878, s. 185; TBMM Kavanin Mecmuast, Devre: X, İctima: 3, c. XXXIX, s. 87.

${ }_{81}$ Duistur, III. Tertip, c. XXXVIII, Kanun No: 7025, s. 1547, TBMM. Kavanin Mecmuası, Devre: X, İctima: 3, c. XXXIX, s. 1086.

${ }_{82}$ Düstur, III. Tertip, c. XXXVI, Kanun No: 6521, s. 1059; Düstur, III. Tertip, c. XXXVI, Kanun No: 6523, s. 1084; Düstur, III. Tertip, c. XXXVI, Kanun No: 6524, s. 1094; Diustur, III. Tertip, c. XXXVI, Kanun No: 6525, s. 1095.

${ }_{83}$ Düstur, III. Tertip, c. XXXVI, Kanun No: 6526, s. 1096; Düstur, III. Tertip, c. XXXVI, Kanun No: 6527, s. 1099; Düstur, III. Tertip, c. XXXVI, Kanun No: 6532, s. 1137, Düstur, III. Tertip, c. XXXVII, Kanun No: 6648, s. 282; Düstur. III. Tertip, c. XXXVIII, Kanun No: 6898, s. 286. 
Savaşı sonrasında yerini alan Türkiye için, siyasi değişmeler yanında ekonomik değişmeler de kaçınılmaz görünüyordu.

İkinci Dünya Savaşı'ndan sonra oluşan ekonomik yapıda yerini almaya başlayan zenginler sınıfı, çok partili yaşama geçiş ve ardından DP'nin iktidarıyla güçlerini iyice perçinleyeceklerdir. Bundan sonra günümüze dek süren bu zengin sınıfının servet edinmeleri iktidar partilerinin taraf tutmalarıyla iyice şekillenecektir. Diğer yandan DP iktidarıyla köyden kente göç hızlı bir şekilde artmış bunun da ekonomik alt yapısı henüz hazır olmayan Türkiye için kötü etkisi olmuştur. Göç olgusu ile birlikte geleneksel tarım ekonomisi değişmiş yerini Amerikan destekli sanayi almıştır. Siyasi alanda olduğu gibi ekonomik alanda da liberalizmi savunan Demokratlar, bunu gerçekleştirmek için yabancı sermayeye önem vermişler ve yerli girişimci sınıfın şekillenmesinde yabancı sermayenin yol gösterici olacağını düşünmüşlerdir. Fakat ekonomide hedeflenen liberalizm iç ve diş etkenler yüzünden sekteye uğramıştır. Bu yüzden yerli girişimci sınıfının oluşması tam gerçekleşmediği gibi ekonomide devlet etkisi devam etmiştir. Bunun sonucunda hükümet, karma ekonomiye yönelmek zorunda kalmıştır.

Bütün bunlara rağmen DP'nin Türk ekonomisine katkısı da olmuştur. Başta geleneksel tarım modelini değiştirerek yerine modern tarım anlayışını getirmeleri önemli atılımlardan biridir. Ayrıca sulu tarım için önem taşıyan baraj yapımına büyük önem verilmesi, sulu tarıma olanak sağladığg gibi elektrik üretimini de artırmıştır. Bu da ileride Türk sanayisinin gelişmesi için gerekli koşullardan biriydi. Buna karşılık Demokrat Parti iktidarlarının uyguladığı sosyal, siyasal ve ekonomik politikalar, Türkiye'nin bugün içine düştügü çıkmazın da en önemli nedeni olmuştur. 